\title{
The dynamics of cultivation and floods in arable lands of Central Argentina
}

\author{
E. F. Viglizzo ${ }^{1,2}$, E. G. Jobbágy ${ }^{2,3}$, L. Carreño ${ }^{1,3}$, F. C. Frank ${ }^{1}$, R. Aragón ${ }^{3}$, L. De Oro ${ }^{2}$, and V. Salvador ${ }^{1}$ \\ ${ }^{1}$ INTA, Centro Regional La Pampa, Area of Environmental Management, Av. Spinetto 785, P.O. Box 3026300 Santa Rosa, \\ La Pampa, Argentina \\ ${ }^{2}$ CONICET, Av. Spinetto 785, P.O. Box 302, 6300 Santa Rosa, La Pampa, Argentina \\ ${ }^{3}$ Grupo de Estudios Ambientales IMASL, Ej. de los Andes 9505700 San Luis, San Luis, Argentina
}

Received: 25 June 2008 - Published in Hydrol. Earth Syst. Sci. Discuss.: 21 August 2008

Revised: 27 February 2009 - Accepted: 27 February 2009 - Published: 9 April 2009

\begin{abstract}
Although floods in watersheds have been associated with land-use change since ancient times, the dynamics of flooding is still incompletely understood. In this paper we explored the relations between rainfall, groundwater level, and cultivation to explain the dynamics of floods in the extremely flat and valuable arable lands of the Quinto river watershed, in central Argentina. The analysis involved an area of 12.4 million hectare during a 26-year period (19782003), which comprised two extensive flooding episodes in 1983-1988 and 1996-2003. Supported by information from surveys as well as field and remote sensing measurements, we explored the correlation among precipitation, groundwater levels, flooded area and land use. Flood extension was associated to the dynamics of groundwater level. While no correlation with rainfall was recorded in lowlands, a significant correlation $(P<0.01)$ between groundwater and rainfall in highlands was found when estimations comprise a time lag of one year. Correlations between groundwater level and flood extension were positive in all cases, but while highly significant relations $(P<0.01)$ were found in highlands, non significant relations $(P>0.05)$ predominate in lowlands. Our analysis supports the existence of a cyclic mechanism driven by the reciprocal influence between cultivation and groundwater in highlands. This cycle would involve the following stages: (a) cultivation boosts the elevation of groundwater levels through decreased evapotranspiration; (b) as groundwater level rises, floods spread causing a decline of land cultivation; (c) flooding propitiates higher evapotranspiration
\end{abstract}

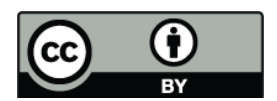

Correspondence to: E. F. Viglizzo (evigliz@cpenet.com.ar) favouring its own retraction; (d) cultivation expands again following the retreat of floods. Thus, cultivation would trigger a destabilizing feedback self affecting future cultivation in the highlands. It is unlikely that such sequence can work in lowlands. The results suggest that rather than responding directly and solely to the same mechanism, floods in lowlands may be the combined result of various factors like local rainfall, groundwater level fluctuations, surface and subsurface lateral flow, and water-body interlinking. Although the hypothetical mechanisms proposed here require additional understanding efforts, they suggest a promising avenue of environmental management in which cultivation could be steered in the region to smooth the undesirable impacts of floods.

\section{Introduction}

Since ancient times, the hydrological dynamics of watersheds were associated to land use/land cover change. Floods were frequently attributed to the conversion of woodlands and grasslands into grazing, cropping and urban lands. Water runoff typically decreases exponentially as plant cover increases (Elwell and Stocking, 1976; Lee and Skogerboe, 1985; Francis and Thornes, 1990) and paired catchment investigations on the hydrological role of vegetation show a general trend of declining evapotranspiration and increasing water yield as plant cover get reduced and as vegetation shifts across the forests-grasslands-annual crop sequence (Bosch and Hewlett, 1982; Calder, 1998; Zhang et al., 2001; Andréassian, 2004). Models and observations indicate that large trees in catchments may deplete groundwater reserves where their roots reach the water table, yet

Published by Copernicus Publications on behalf of the European Geosciences Union. 
their effect can be contrasting between temperate/tropical and wet/dry regions (Le Maitre and Versfeld, 1997; Calder 1998).

Beyond its effect on water yield, the effect of cultivation on groundwater levels and its relation to land flooding has been less studied and is still poorly understood. Because of the expansion of saline areas in agricultural lands of Australia, Ferdowsian and Bee (2006) reported an excessive groundwater recharge under traditional cultivation that led to the rising of the water table. They recommended the use of deep-rooted perennial pastures (such as alfalfa) to reduce recharge and lower water level.

As it happens in complex systems (Jeong et al., 2000), the large scale dynamics of flooding processes are also essentially unknown. Holistic approaches are necessary to improve our knowledge and forecasting ability (Clark et al., 1988). Data from long-term series have supported watershed studies, but they are frequently criticised because most research was focused on certain spatial scales (Hornbeck et al., 1993). This is a relevant issue because agronomists, ecologists, environmentalists, land managers, policy makers and development agents who make decisions at different levels (plot, farm, ecosystem, landscape, eco-region) increasingly demand scientific information about cross-scale relations and interactions in hierarchical systems (Viglizzo et al., 2005). Some authors (Buringh and Dudal, 1987; Bailey 1995; O'Neill et al., 1991; Wagenet 1998) have stated that high-level environmental factors like landform, climate and land quality have strong top-down influence on lower levels. On the other hand, human-dependent factors at lower levels, such as land-use and management, may exert bottomup influences, that are smoothed at successively higher levels (King, 1993; Viglizzo et al., 2004).

In this paper we (1) describe the dynamics of flooding in the central Pampas of Argentina and (2) revise their triggering mechanisms, based on the analysis of $\sim 30$ year-long temporal series of precipitation, land cultivation, groundwater levels, and flooded area for the so-called Quinto river watershed $\left(124000 \mathrm{~km}^{2}\right)$. Lowlands in the watershed represent a typical case of flood-prone area in the Pampas, where regular floods undermine the regional economy (Fuschini Mejía, 1994). To guide our analysis we propose two extreme and simple hypotheses that explain the onset of floods in the study watershed, acknowledging that a more complex combination of both is most likely taking place. Our climateoriented hypothesis suggests that flooding is the result of increased precipitation inputs, which accumulated through a certain period, causes a widespread elevation of groundwater levels that eventually reach the surface and limit cultivation. Our ecosystem-oriented hypothesis, on the other hand, proposes that flooding emerges as a result of increasing cultivation, which enhances recharge and raises groundwater level when high water-consuming pastures and grasslands are replaced by low water-consuming annual crops. In this paper we explore the temporal variation and correlation of rainfall, groundwater level, flooding and cultivation, and use our extreme guiding hypotheses to explain the development of flooding, and suggest possible non-linear interactions and feedback mechanisms that might regulate the system.

\section{Materials and methods}

In order to understand the dynamics of floods in the study area, the associations among rainfall, groundwater and cultivation were explored. We use the term cultivation to indicate the proportion of arable land that is allocated to extensive grain crops (mainly wheat, soybean, maize and sunflower) every year, based on the fact that the rest of the land is typically occupied by perennial pastures (Hall et al., 1992).

\subsection{The study region}

The Argentine Pampas $\left(33-35^{\circ} \mathrm{S}, 62-64^{\circ} \mathrm{W}\right)$ is a wide plain of around 54 million hectare of fertile lands suiTable for cattle and crop production (Hall et al., 1992; Viglizzo et al., 2001). Soil quality varies (Satorre 2001) and rainfall declines from NE to SW. The climate of the Western Pampas is temperate (mean annual temperature $=16.2^{\circ} \mathrm{C}$ ) with $70 \%$ of rainfalls, that average $750 \mathrm{~mm}$ year $^{-1}$ (Díaz Zorita et al., 1998), occurring between October and April. Winds are more intense (around $16.8 \mathrm{~km} \mathrm{~h}^{-1}$ ) and frequent (only 14\% of calmed days) during the hot season (Hall et al., 1992), triggering wind erosion episodes. Cyclical drought and flood episodes that affect both crop and cattle production have been described by Viglizzo et al. (1997) and Moncaut (2001).

The Western or "Sandy" Pampas (Fig. 1) occupy approximately one third of the region and consist of a large and complex system referred as the "Sand Sea" that comprise a large regional configuration of longitudinal, mega-parabolic dunes (Iriondo, 1990). The region was shaped during the last Pleistocene glaciation and was partially reworked during later desertification episodes (Iriondo, 1999), particularly during the 1930-1940's dust bowl that affected the Western Pampas (Zarrilli, 1999, Fig. 1b). The linear features normally observed in satellite images correspond to a succession of elongated mounds and inter-dune depressions that constrain the natural evacuation of water (Malagnino, 1991). The Late Pleistocene-Holocene deposits provide the parent material for the modern cultivated soils (Zárate, 2003).

In hydrological terms, the region comprises an active groundwater system that is the result of the convergence of Araucana, Puelche and Pampeana formations, being the last one the top of the aquifer, which is relatively shallow (Aradas et al., 2002). Very often, rainfall adds to already water saturated soils and leads to multiple ephemeral water bodies that, depending upon topographical configurations, can join and produce extensive flooding episodes (Aradas et al., 2002). Losses from the system occur by runoff and vertical water fluxes that involve infiltration, evaporation and 

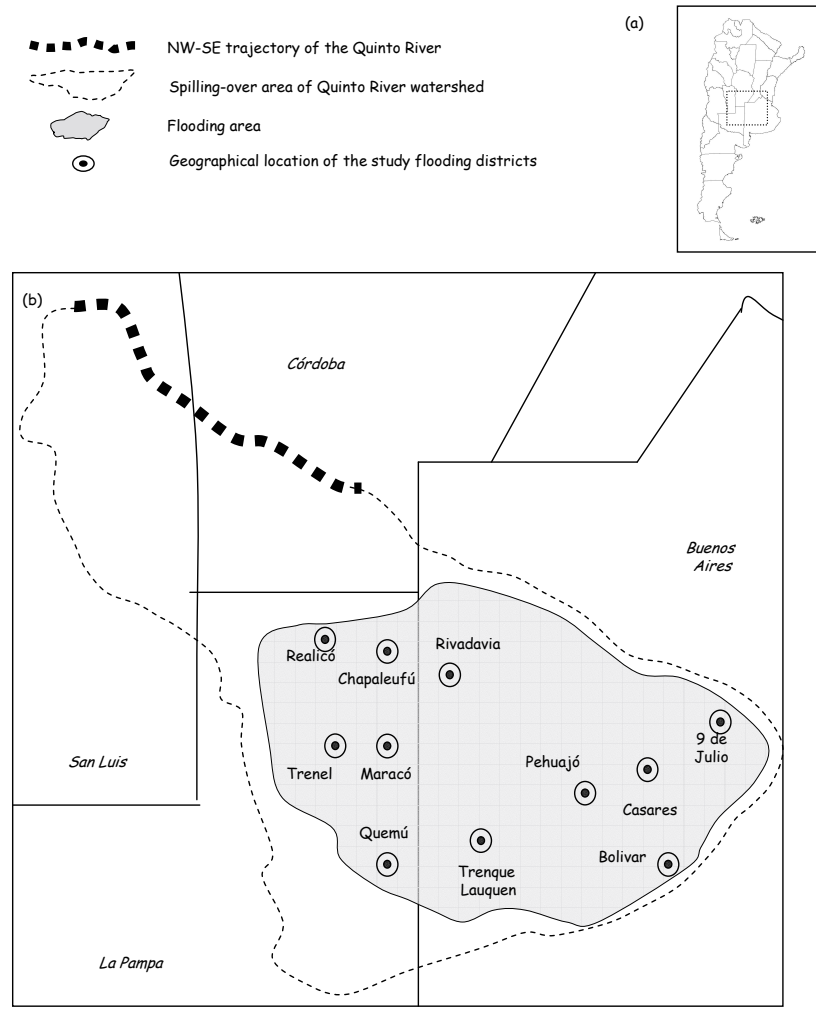

Fig. 1. Location of the Quinto river watershed shared by San Luis, La Pampa, Córdoba and Buenos Aires provinces; (a) location of the Western Pampas and the watershed in the Argentine territory, (b) detail of the watershed showing the spill-over area, the flooding area, the Quinto river trajectory and the geographical location of the study districts.

evapotranspiration from a plethora of occasional lakes and wetlands (Scarpati et al., 2002). In order to relieve vulnerable lands from flooding and water-logging problems in part of the region, and also to improve conditions for agricultural production, the political authority of Buenos Aires province commissioned in 1987 the elaboration of an Integrated Master Plan (Saravia et al., 1987) that later was only partially carried out.

\subsection{The Quinto river watershed}

Topographic watershed boundaries in this region are poorly defined since no river or stream channels are evident and most surface water bodies correspond to ponds and lagoons. The extremely flat territory located at the SE of the lower Quinto River, focus of our study, does not behave as a conventional basin. In periods of high rainfall the Quinto River may extend its landlocked basin beyond its natural end point in the lagoons of La Amarga (Carignano, 1999), bringing water to our study area. However, with the exception of extreme flooding events, the water budget of the study area is mainly explained by local rainfall inputs with only small con-

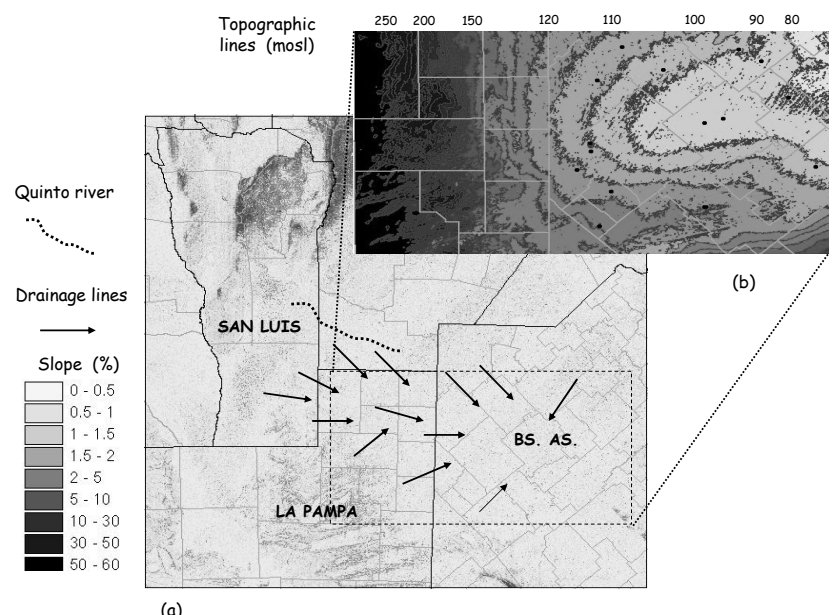

Fig. 2. (a) graphic of Fig. 1 showing a slope class map of the area of the Quinto river watershed, the Quinto river trajectory and the drainage lines, (b) topographic features of the flooding area from Landsat images showing the strip that separates highlands from lowlands on $110-120 \mathrm{~m}$ on sea level.

tributions coming from outside its boundaries (Kruse, 1992; Kruse et al., 2001). Our delimitation of the Quinto river basin is only geographical and acknowledges the fact that this portion of the Pampas have a rather anarchic and endorreic drainage system.

The plain where floods occur is in part located inside the Western Pampas. It extends from NW to SE following a topographic gradient that ranges between $900 \mathrm{~m}$. in the central hills of San Luis province (outside the Pampas), to less than $100 \mathrm{~m}$. above sea level (m.a.s.l.) on the flooding lowlands of NW Buenos Aires province. As it can be appreciated in the slope-class map (Figure 2a), an extremely gentle slope (mean: $0.525 \%$, SD: 0.423 ) dominates the whole study area. A broad-scale NE-SW spill-over area (of around 12.3 million hectare) raises along the river, which favours water drainage into a flooding plain that comprise highly productive and valuable lands in which cultivation has increased since the 1960s (Viglizzo et al., 2001). Arrows in Fig. 2a represent surface streams based on surface land elevation. Drainage is relatively robust in the higher part of the watershed (hereafter highlands) because of the steep topographic gradient that cuts across the southern districts of San Luis and Córdoba provinces. The lower part of the watershed (hereafter lowlands) is, on the other hand, a flat depression that extends over the NE districts of Buenos Aires province with elevations ranging from 130 and 50 m.a.s.l. Despite flatness, episodes of weak drainage that are mediated by occasional interlinked water bodies and anthropic constructions such as channels and roads occur inside the lowlands (Kruse et al., 2001; Kruse and Zimmermann, 2002). Despite large differences, both highlands and lowlands are prone to flooding. 
Table 1. Correlation analysis between estimations of flooded areas from satellite images and from field-data.

\begin{tabular}{llll}
\hline & District & $\begin{array}{l}\text { Correlation } \\
\text { coefficient }(R)\end{array}$ & $P$ value \\
\hline Highlands & Chapaleufú & 0.89 & $<0.01$ \\
& Realicó & 0.74 & $<0.05$ \\
& Trenel & 0.74 & $<0.05$ \\
& Quemú & 0.81 & $<0.05$ \\
& Maracó & 0.81 & $<0.05$ \\
Lowlands & Bolivar & 0.83 & $<0.01$ \\
& 9 de Julio & 0.87 & $<0.01$ \\
& Rivadavia & 0.68 & $<0.05$ \\
& Casares & 0.56 & $>0.05$ \\
& Pehuajó & 0.54 & $>0.05$ \\
& Trenque Lauquen & 0.65 & $<0.05$ \\
\hline
\end{tabular}

We used different sources of information to place the limit between highlands and lowlands. In first place we used a digital elevation model (DEM) that included most of the Rio Quinto watershed to identify sharp shifts in slope and elevation. Independently we worked with a Landsat scene (227$85,32400 \mathrm{~km}^{2}$ ) that covers the transition zone within the watershed to characterize "baseline" flooding intensity based on the total area covered by ponds during the dry year of 1997. Elevation ranges between 300 and $80 \mathrm{~m}$, gradually decaying towards the SE. The topography is extremely flat with $90 \%$ of the area having $<1 \%$ slope. A pronounced slope shift takes place across the range of 110-120 m.a.s.l. contour line. Using this contour as a limit for highlands and lowlands, the mean elevation and slope for the two regions were, respectively, $183 \mathrm{~m}$. and $0.73 \%$ and $91 \mathrm{~m}$ and $0.45 \%$. Based on the 1997 Landsat scene, the area covered by water bodies was $2 \%$ for highlands and $6 \%$ for lowlands (Fig. 2b).

\subsection{Data sources and analysis}

Data on latitude, longitude and landform were obtained from field measurements, satellite images and topographic maps. Land-use datasets were provided by the Annual Agricultural Surveys for the period 1978-2003 provided by the Secretary of Agriculture of Argentina. Public hydrological organizations (The Provincial Water Administration in La Pampa and The Plains Hydrology Institute in Buenos Aires provinces) and the National Meteorological Services provided iii) longterm precipitation data and iv) groundwater level records from a large network involving 58 phreatimetric nodes scattered among 29 locations. A subset of 11 of these data points (see Fig. 1) had continuous and homogenous data for the whole study period.

We focused our work at two spatial and temporal scales: A broad-scale analysis for the 1978-2003 period comprising highlands and lowlands as whole units in the flooding area, and a small-scale analysis for the 1996-2003 period. Data were disaggregated into eleven political districts (five located in highlands, and six in lowlands), which are the smallest unit in which public surveys of land use are organized. To study the dynamics of cultivation and floods along a 25 -year period we relied on existing records (on land use, precipitation and groundwater level) from different sources (see above in this section). Mean values and standard deviations were respectively used to characterize the patterns of precipitation, groundwater level and \% of cultivation at the broad highland and lowland scales during 1978-2003. Simple correlation analyses using best-fitting linear models were used to evaluate relations at both scales. Given that the relation between rainfall and groundwater is essential to interpret our results, we explored eventual time lags ( 0 to 6 years) between both variables through correlation analysis.

Correlation analysis were used at the district level during the period of 1996-2003 to estimate the degree of association between a) the groundwater level and the \% of croplands affected by floods and $b$ ) the change of cultivation during the inter-flooding period of 1989-1995 and the groundwater level during the 1996-2003 flooding period. It should be noticed that cultivation increased in all districts during the inter-flooding period (Viglizzo et al., 2001).

Given that no numerical measurements of flood extension were available for the last 30 -year period we estimated it based on the values of reduction of cultivated area obtained from survey data for the 1996-2003 flooding event. This estimate assumed that the cultivated area was exclusively reduced by flooding. To validate this procedure, we relied on the support of satellite images in order to estimate the extension of flooded lands along the flooded period of 19962003. Smith (1997) provided a brief review about the use of active and passive remote sensing to map surface water and flooding, including the development of correlations between ground level indicators and satellite data. We followed this last approach based on the correlation of cultivated area extent (assumed to be constrained by floods) and surface water coverage characterization with LANDSAT images. In Table 1 , we show the correlations coefficients $(R)$ and their statistical signification ( $P$ value) for highlands and lowlands districts. Considering that correlation coefficients $(R)$ ranged between 0.54 and 0.89 and were significant $(P<0.01$ or $P<0.05)$ in nine of the eleven study districts, we assumed that the reduction of the cultivated area is an appropriate estimator of flood extension.

\section{Results and discussion}

\subsection{Precipitation, groundwater and cultivation at whole region level}

While homogenous behaviour of land use across districts of the Western Pampas prevailed until the middle of the 
Table 2. Broad-scale correlation analyses.

\begin{tabular}{llllllll}
\hline & \multicolumn{2}{c}{ Correlation between } & $\mathrm{a}$ & $\mathrm{b}$ & $R$ & $\mathrm{SE}$ & $P$ value \\
\hline \multirow{2}{*}{ Highlands } & Rainfall & Groundwater level & -4.48 & 0.002 & 0.46 & 141.17 & $<0.05$ \\
& & $\%$ annual crops & -6.79 & -0.006 & -0.09 & 158.52 & $>0.05$ \\
\multirow{4}{*}{ Lowlands } & Groundwater level & $\%$ annual crops & 37.04 & -6.790 & -0.41 & 0.56 & $<0.05$ \\
& Rainfall & Groundwater level & -2.37 & 0.000 & -0.06 & 130.37 & $>0.05$ \\
& & $\%$ annual crops & 51.67 & -0.015 & -0.28 & 125.50 & $>0.05$ \\
& \multirow{2}{*}{ Groundwater level } & $\%$ annual crops & 28.85 & -2.520 & -0.23 & 0.64 & $>0.05$
\end{tabular}

References: Correlation analysis between rainfall, groundwater level and \% of annual cultivation in flooding lands of the spill-over area within the Quinto river watershed during a 26-year period (1978-2003).
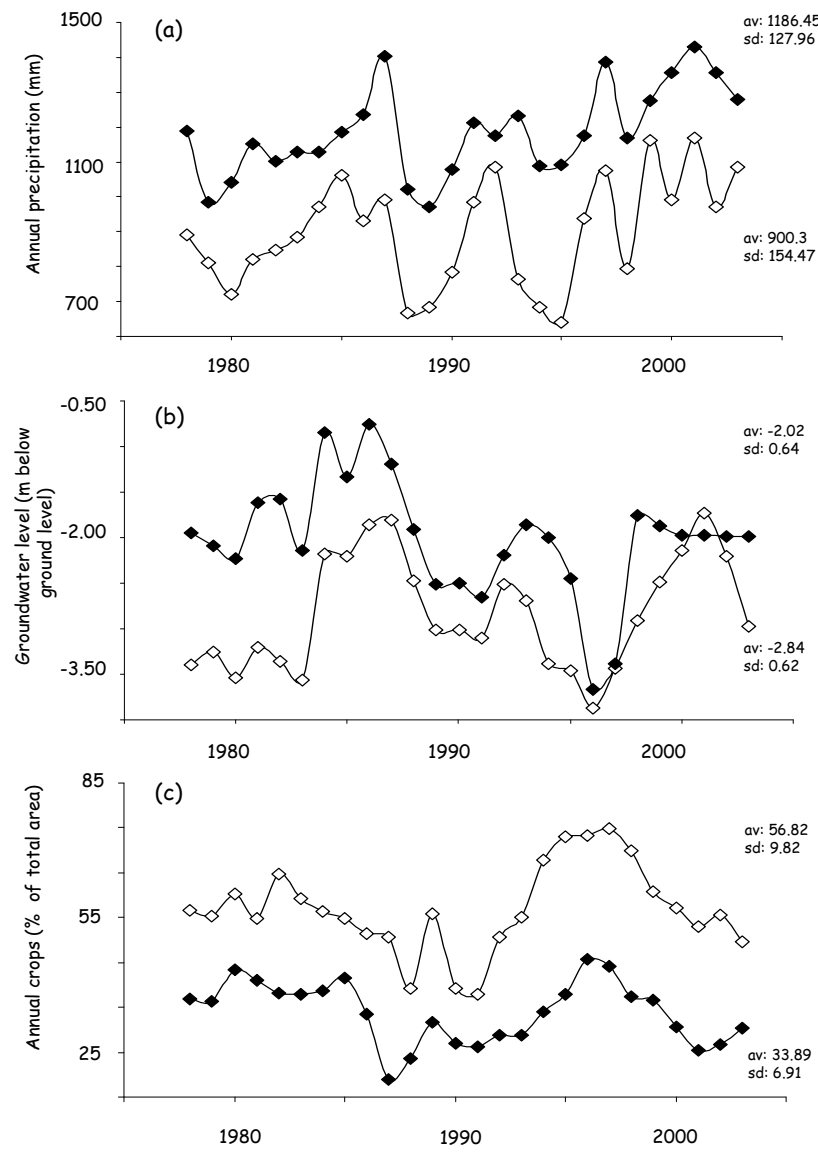

Fig. 3. Temporal variability in patterns of (a) precipitations, (b) groundwater level, and (c) annual cultivation in highlands (white symbols) and lowlands (black symbols) within the spill-over area of the Quinto River watershed during the period 1978-2003. Av: average value, sd: standard deviation. Analyzed period: 1978-2003.

20th century, a decoupling of flooded vs. non-flooded regions emerged during the high-rain period initated in the 70‘s (Viglizzo et al., 1997, 2001). Throughout the 25 year study period (1978-2003) highlands and lowlands displayed similar trends in precipitation, groundwater level and cul- tivated area, with correlation coefficients between regions of $0.75,0.64$ and $0.70(P<0.01)$. Highlands had on average lower precipitation, deeper groundwater, and more cultivation than lowlands (Fig. 3a). In spite of having lower precipitation variability, lowlands displayed similar groundwater level variability than highlands, with water tables being on average $80 \mathrm{~cm}$ shallower throughout the study period (Fig. 3b). Highlands averaged $50 \%$ of cultivated area, peaking of 70\% in 1995-1997 (Fig. 3c), whereas in lowlands these values were $34 \%$ and $45 \%$, respectively.

Rainfall-groundwater and rainfall-cultivation associations were weaker than groundwater-cultivation (Table 2). While rainfall and groundwater level are positively and significantly $(P<0.05)$ correlated in highlands, such correlation is not significant $(P>0.05)$ in the case of lowlands. The relation between rainfall and cultivation was non significant $(P>0.05)$ in both areas, but the correlation coefficient was substantially higher in lowlands than in highlands. This supports the notion that while groundwater might have a larger effect in highlands than in lowlands, rainfall might be more influential in lowlands. We found no correlation between rainfall and groundwater level in lowland sites, in agreements with previous findings for the Flooding Pampas, east of our study region (Paruelo and Sala, 1990). In highland sites, however, the introduction of lags revealed a delayed response of groundwater levels to rainfall in previous years, with correlations peaking with a one-year lag $(R=0.56, p<0.01)$. The lack of correlation in lowlands could be interpreted as follows: i) water tables are always shallow and less sensitive to precipitation supplies; ii) surface or iii) subsurface water transport from highlands are a more important control of groundwater levels than local rainfall.

Simple input-output correlation analysis may not capture complex interactions in the flooded landscapes. Nonlinearities and multiple interactions between climatic, geological and biological factors could increase the complexity of surface-subsurface water interactions (Tóth 1970, Sophocleous 2002). In flat sedimentary landscapes, surface-water bodies can be integral parts of the groundwater flow system being both foci of recharge and discharge depending on 

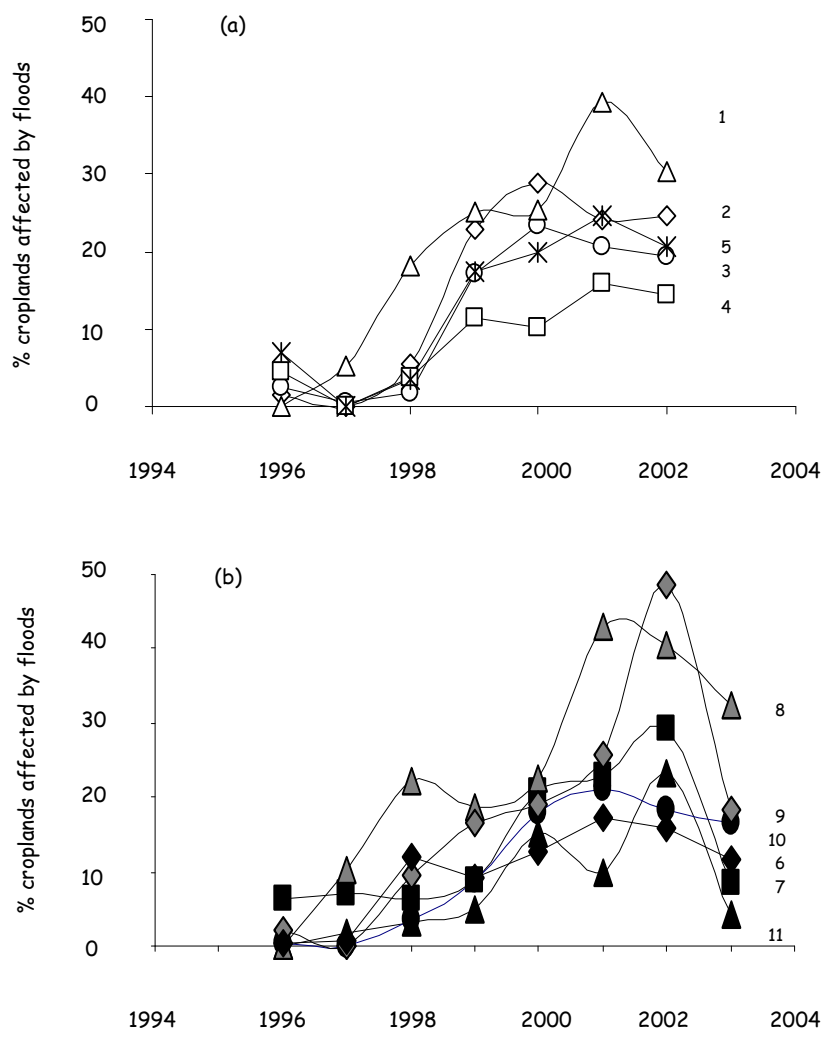

Fig. 4. Percentage of cropland affected by floods during the period 1996-2003 in the flooding area of the Quinto River basin. Highland districts (a) comprise 1. Chapaleufú, 2. Realicó, 3. Trenel, 4. Quemú , 5. Maracó $(R=0.67, P<0.01)$. 1996-2002 was the period covered by floods in highlands. Lowlands (b) comprise 6 . Bolivar, 7. Rivadavia, 8. 9 de Julio, 9. Casares, 10. Pehuajó, 11. Trenque Lauquen. 1996-2003 was the period covered by floods in highlands.

the location and regional flooding situation (Winter, 1999). In these complex system vegetation, can influence runoff, groundwater recharge/discharge, affecting both groundwater levels and flooded area (Jobbágy and Jackson, 2004; Rodríguez-Iturbe et al., 2006; Montaldo et al., 2005; Manfreda and Fiorentino, 2008). For this reason analyses based solely on groundwater-climate links may fail to explain the hydrological dynamics of basins and flooding plains.

For our purposes, whenever we use rainfall or groundwater arguments to explain flooding, both tend to support our climate-oriented hypothesis, which suggests that floods are the result of increased precipitation that directly expands water bodies, or indirectly cause a widespread elevation of groundwater that saturates land surface and limits cultivation. Nevertheless, in isolation, this hypothesis seems to be unable to explain the potentially cyclical behaviour of floods and cultivation.
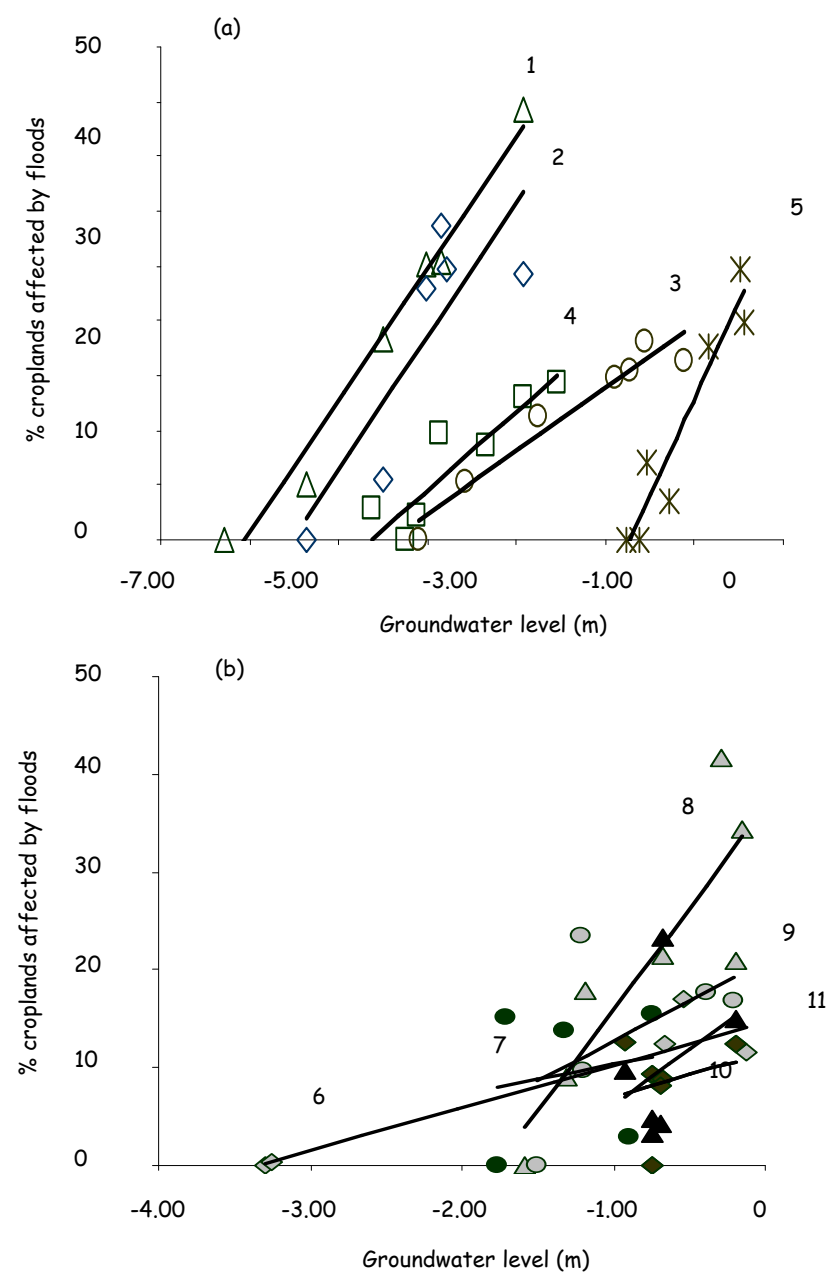

Fig. 5. Relationships between groundwater levels and \% of cropland affected by floods in the flooding area of the Quinto River basin during the period 1996-2003. Highland districts (a) comprise 1. Chapaleufú $(R=0,99, P<0.01), 2$. Realicó $(R=0.84, P<0.01)$, 3. Trenel $(R=0,97, P<0.01)$, 4. Quemú $(R=0.91, P<0.01), 5$. Maracó $(R=0.95, P<0.01)$. Lowlands district (b) comprise 6. Bolivar $(R=0.92, P<0.01)$, 7. Rivadavia $(R=0.18, P>0.05), 8.9$ de Julio $(R=0.86, P<0.05), 9$. Casares $(R=0.26, P>0.05), 10$. Pehuajó $(0.23, P>0.05), 11$. Trenque Lauquen $(R=0,35, P>0.05)$. 1996-2003 was the period covered by floods in highlands.

\subsection{Groundwater and floods at the district scale}

Considering the predominant and significant positive correlations between survey and satellite data to estimate the extension of floods, we proceeded on our analysis by using the first set of records from annual surveys. Three aspects of the dynamics of flooded area can be highlighted (Fig. 4): i) Lowlands showed a more disperse and erratic behaviour than highlands, where a relatively homogeneous flooding pattern predominated, ii) the flooding extension picked one year earlier in highlands than in lowlands, probably suggesting a slow transference of water from highlands to lowlands. In 
fact, when floods began to decrease in highlands (2002), they showed maximum expansion in lowlands (2003).

District-scale results showed contrasting flooding and cultivation dynamics and association in highlands and lowlands (Fig. 5). Setting aside the fact that correlations were positive in all study districts, relations were unambiguous and highly significant $(P<0.01)$ in highlands but rather anarchic and non-significant $(P>0.05)$ in lowlands. While groundwater level seems to play a dominant triggering role of floods in highlands, drivers other than groundwater seem to predominate in lowlands. Because of the flat landscape, it is likely that factors such as local rainfall, subsurface drainage, and the coalescence of scattered water bodies facilitating surface water transport patterns could play a role during wet periods.

The Pampas are an extremely flat setting, with regional slopes of $<0.01 \%$ (Tanco and Kruse, 2001; Jobbágy et al., 2008). In most of the Pampas, however, small-scale slopes (across distances of less than $1 \mathrm{~km}$ ) are larger than regional slopes because of the dune landforms shaped by intense aeolian activity during the Holocene. In this context, local hydraulic gradients overwhelm regional ones, favouring local flow systems over intermediate and regional ones (sensu Tóth, 1963). Under these conditions the expansion of flooded areas is associated with gradual water level raises and the eventual coalescence of ponds and shallow lagoons. Accumulated water excesses cannot be stored in the unsaturated zone that gets thinner and is unable to host additional water inputs. As a result, surface water bodies emerge across the lowest portions of the landscape. Floods in most of the Pampas are more likely to develop through saturation-excess overland flow and subsurface flow than through infiltration excess or Hortonian flow (Sophocleus, 2002). Local influences on recharge and discharge fluxes could play a strong role in the Pampas, regulating the water budget (and area) of ponds and lagoons (Meyboom, 1967). For this reason the dynamics of floods are not of high frequency (i.e. flash floods) but of slow initiation and even slower retraction.

Flood retraction can be explained through direct evaporation from sporadic lagoons and water bodies. Tank evaporation (A-tank) records are unavailable in the study region. However, two stations located in a drier climate, $50 \mathrm{~km}$ towards the west (Anguil), and in a cooler and moister climate, $300 \mathrm{~km}$ towards the southeast (Balcarce) achieve average values of 2009 and $1011 \mathrm{~mm} / \mathrm{yr}$ for 1976-2006 (Casagrande, personal communication). Even the lowest of these values is higher than those typically reported for annual crops with unlimited water supply (Carcova et al., 2000; Gardiol et al., 2003), suggesting that pond evaporation could become a more effective vapour evacuation pathway than transpiration to remove water once flooding expands. This contrast between pond evaporation and transpiration may be even more dramatic if the effects of waterlogging, curtailing water consumption by crops are considered (Meyer et al., 1987). In this case, water level raises may trigger a positive feedback on flooding in a first stage, caused by transpiration inhibition, but a negative feedback on a second stage, motorized by the high evaporation rates achievable under tank conditions.

\subsection{The potential effect of cultivation on flooding}

Our ecosystem-oriented hypothesis can provide an extra insight on flooding dynamics. Two hydrological mechanisms have been suggested to explain the potential influence of cultivation on flooding: increased runoff and decreased evapotranspiration (ET). Various authors (Fullen, 1985; Faulkner, 1990; Evans, 1993; McNeill and Winiwarter, 2004; Withers et al., 2007) have reported that cultivation is likely to increase surface runoff and flooding. On the other hand, ET rates can decline in cultivated lands (Newman et al., 2006). Changes of ET in response to land use change proved to have a powerful effect on soil water balance (Wilcox et al., 2003, Nosetto et al., 2005; Wilcox and Thurow, 2006) in turn affecting groundwater level (Scanlon et al., 2005). The timing of groundwater raise in relation to land-use/landcover change is not still well understood, but different spatial and temporal plant-cover configurations can create different ET patterns (Gilfedder et al., 2003). While perennial vegetation tends to show long-term and rather continuous ET patterns, annual crops show short-term ET pulses that agree with periods of active growing (Doorenbos and Pruitt, 1977). Therefore, it is expected that the substitution of permanent or perennial plants by annual crops may reduce ET rates, and eventually increase groundwater level because of a shortened growing period. In Australia, Allison et al. (1990), Ward et al. (2006) and Ferdowsian and Bee (2006) reported that the broad-scale clearing of perennial vegetation and its replacement by annual crops and annual pastures has resulted in rising groundwater levels. An additional aspect that may restrain ET once the onset of floods has taken place is the fact that land with the water Table close to the surface (e.g. $<0.8 \mathrm{~m}$ deep) often ceases to be sown and is deprived from plant transpiration. This process can proceed until groundwater reaches the surface and direct surface evaporation occurs. There is an incomplete understanding about the time lag between land-use change and groundwater level change, but today this information is essential to design sound land use and land management strategies (Gilfedder et al., 2003). Given that both the percentage of annual crops and the flooded croplands were estimations obtained from the same data source, any correlation between them would inevitably connote circular calculation and spurious results. To manipulate independent data periods, we alternatively explored the correlation between cultivation during the inter-flooding period (1989-1995) and groundwater level during the flooding period (1996-2003). The notion that increasing cultivation could lead to groundwater elevation was supported by a positive correlation observed in all highland districts (Fig. 6a). This response gives room to speculate that the increase of cultivation during the inter-flooding period can trigger groundwater elevation that later saturates the soil 

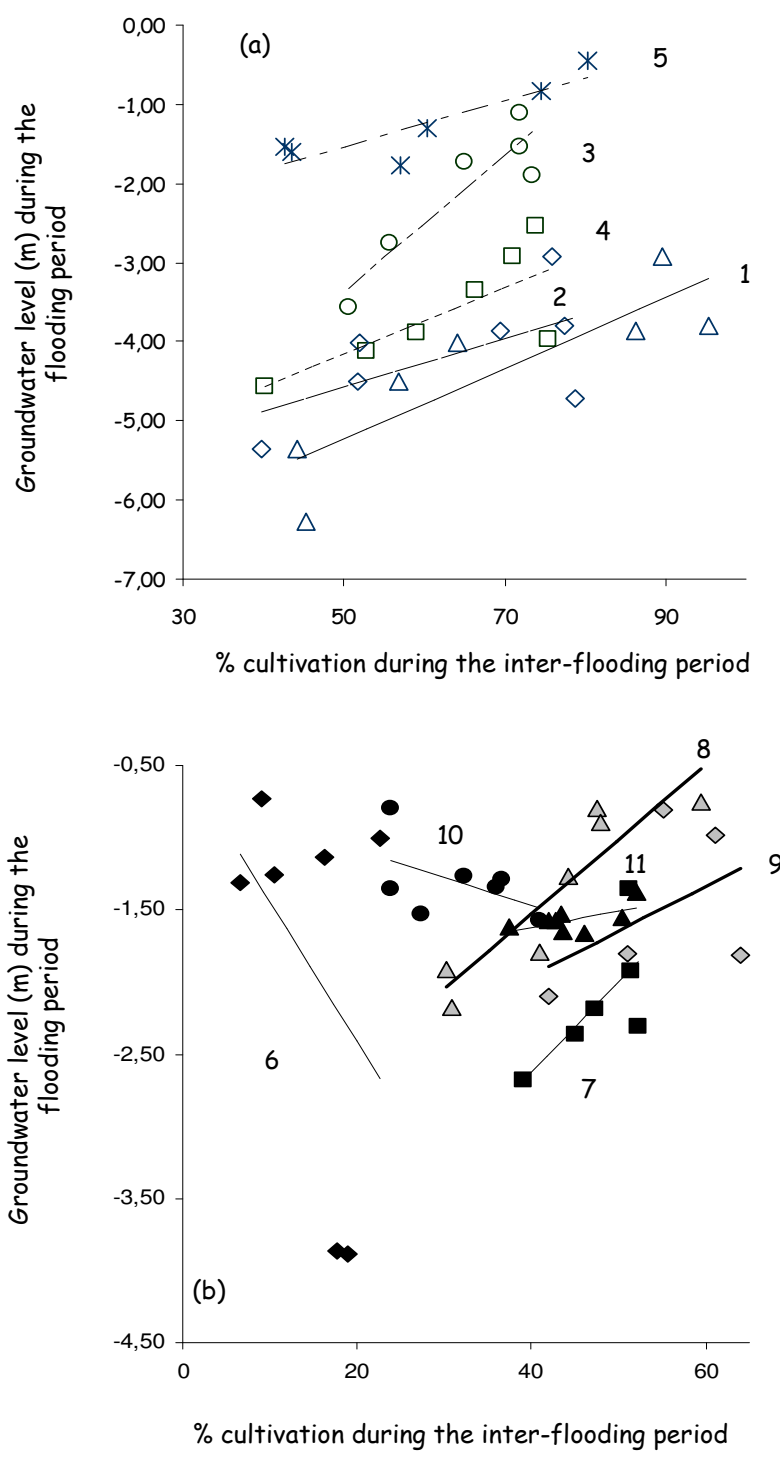

Fig. 6. Relationships between $\%$ cultivation during the interflooding period (1989-1995) and groundwater levels during the flooding period 1996-2003. Highland districts (a) comprise 1. Chapaleufú $(R=0,86, P<0.01), 2$. Realicó $(R=0.61, P>0.05)$, 3. Trenel $(R=0,92, P<0.01), 4$. Quemú $(R=0.75, P<0.05), 5$. Maracó $(R=0.88, P<0.01)$. Lowlands districts $(\mathbf{b})$ comprise 6 . Bolivar $(R=-0.42, P>0.05), 7$. Rivadavia $(R=0.70, P>0.05), 8.9 \mathrm{de}$ Julio $(R=0.91, P<0.01)$, 9. Casares $(\mathrm{R}=0.48, P>0.05), 10$. Pehuajó $(-0.51, P>0.05)$. 1996-2003 was the period covered by floods in highlands.

and expands floods. Thus, with a variable time lag, increased cultivation in one period would reduce the chance of cultivation in the following period. This interpretation is consistent with our ecosystem-oriented hypothesis, which proposes that flooding possibly responds to increasing cultivation, which enhances recharge and raises groundwater level when high water-consuming pastures and grasslands are replaced by low water-consuming annual crops. However, in principle this interpretation is not strictly applicable to lowland districts (Figure 6b), which showed a more randomlike behaviour that deviates from that showed by highlands. Probably, the same multiple drivers of flood mentioned above generated noisy responses.

The negative relationship between groundwater and cultivation may have practical implications in highlands: first, groundwater level can be useful to predict a cultivation reduction in response to flood expansion; second, considering the slow movement of groundwater in soils, groundwater level can be monitored to anticipate flood risk, helping to cope in advance with its potentially harmful consequences. However, this reasoning line deserves more explanation. There is a considerable time lag between the interflooding period (1989-1995) and the subsequent flooding period (1996-2003). Thus, while cultivation expansion during the inter-flooding period of 1989-95 can explain groundwater rise in highlands, high water Table contributed to remove land from cultivation during the flooding period 1996-2003. Hypothetically, a delayed negative feed-back may have operated: it is likely that the rapid cultivation expansion during the inter-flooding period triggered a negative feed-back that caused, through floods, a retraction of cultivation during the later flooding period. Given that groundwater showed a smooth rise (around $50 \mathrm{~cm} /$ year) since 1996, we think that this persistent rising trend could have been used to anticipate the maximum flood expansion that occurred during 2001 and 2002.

\subsection{Cyclical behaviour and the ecosystem-oriented hy- pothesis}

A complete and useful compilation of drought and flooding episodes that occurred in the Argentina Pampas between 1576 and 2001, reconstructed through historical chronicles and numerical data by Moncaut (2001), indicates that flooding was a natural episode that repeated cyclically in the history of the study region. Given the qualitative nature of such information, quantification was not possible. Considering that colonization of lands in the study area started between the end of the 19th and the beginning of the 20th century, it is likely that cultivation affected the intensity and frequency of flooding episodes. The rapid cultivation wave that began at the end of 1970's and still persists probably untied a force that destabilized the hydrology of the flooding lands. The abrupt transition from cultivation to flooding, and again to cultivation, especially in highlands, suggests that both hydrology and cultivation are probably subjected to a cyclical behaviour.

One hypothetical interpretation to this cycle is that the competition between amplifying (positive) and controlling (negative) feedbacks is probably modulating the hydrological response of flooding lands. The inversion of phases within each cycle probably occurs when one feedback dominates over the opposite one. By triggering a positive feedback, 
cultivation could destabilize the hydrological balance of the area. On the other hand, floods could trigger a negative feedback that forces the ecosystem to a lower cultivation level that would stabilize the regional hydrology. While positive and negative feedbacks may be mutually neutralizing in a sequential order, we can presume that the flooding process moves between two (upper and lower) critical thresholds that, in theory, were not still irreversibly surpassed (Scheffer et al., 2001; Rial et al., 2004). The consequences of positive feedbacks prevailing over the negative ones in the long term are pure speculative at this point, yet the possibility of irreversibly surpassing threshold as stated by Peters et al. (2004) and Briske et al. (2006), should be considered.

Beyond the competing-feedback interpretation to explain cycles, one answered question in our ecosystem-oriented hypothesis is what can explain water withdrawal once flooding extension peaks. Flooding can favour vertical water-loss pathways through pan-evaporation from water bodies, hypothetically surpassing the ET rates observed under any herbaceous vegetation cover. Another vertical pathway can be the slow infiltration process that later causes lateral subsurface drainage to lower lands. Flooding water can also overflow beyond the watershed boundaries and connect large chains of water bodies, favouring surface flows towards the Atlantic Ocean. This situation was observed under the extreme flooding conditions of 2001 when the Quinto river watershed get a surface connection with the Eastern Salado river watershed (Scarpati et al., 2002). Certainly, a nested-scale configuration seems to be necessary to interpret the agro-eco-hydrological dynamics of the study region.

\section{Conclusions}

Our findings are useful to interpret the complex and dynamic relations between rainfall, groundwater level and cultivation in flooding lands of the Western Pampas. Firstly, we reached the conclusion that this region, often referred as the "Quinto river basin" does not behave as a conventional watershed but as an extensive flooding plain that holds water coming from various sources and through multiple pathways, and not only from Quinto river spills. The long-lasting confusion is probably the ineviTable consequence of misinterpreting the complex hydrological dynamics of a flat aeolian landscape. Secondly, results indicate that a purely climate-oriented perspective that sets aside essential biological aspects like those related to land-use and land-cover change may be insufficient to explain the potential cyclical behaviour of floods and cultivation, and a complementary, ecosystem-oriented view, may be required. Cultivation may have a strong influence on the dynamics of groundwater and floods in the highlands of the study region. In practice, cropping would cause a negative self-impact that could deplete cultivation in the near future. Besides, because of its location in an upper transitional drainage area, the hydrological effect of cultivation in highlands could indirectly contribute to alter the dynamics of floods in lowlands. So, on broad-scale basis, both the climate- and the ecosystem-oriented hypothesis should not be considered mutually excluding but complementary.

Mediated by groundwater variability, the recurrent occurrence of cultivation-flooding cycles appears to be an outstanding feature of highlands that is not so evident in lowlands. Floods in lowlands appear to be the combined result of various factors that may include not only groundwater variations, but also local rainfall inputs, runoff from upper lands, subsurface drainage and interlinking of water bodies. Considering the flatter configuration of lowlands, such factors can converge to mask a foreseeable relation between groundwater and flooding.

Taking into account the relative importance of groundwater in highlands as a driver of flood, land planners and decision makers can take advantage of this condition to prevent catastrophic situations: the slow pace of groundwater processes is suiTable to implement an early-warning monitoring system to facilitate adaptation before the flooding outbreak. Likewise, a knowledge-based land-use policy for highland should not discard the potential effect of cultivation on flooding. To deal with this, we suggest the following hypothetical mechanism to explain the cultivation-flood relation: first, cultivation boosts the elevation of groundwater level through decreased evapotranspiration; second, as groundwater level rises, floods spread causing a decrease of land cultivation; third, flooding propitiates higher evaporation favouring its own retraction. Despite nowadays most drivers of the hydrological dynamics escape to human control, cultivation emerges a promising human-controlling factor that could be managed to smooth the undesirable impact of floods. This view would become more relevant under a wetter climate scenario like that the IPCC (2007) report predicts for the Argentine Pampas.

Given that drainage from highlands appears to be a strong factor affecting the lowlands hydrology, a sensible land-use policy should treat the flooding area a whole hydrological unit. In practical terms, the combination of an engineered channel-infrastructure plus a designed plant-cover structure in highlands seems to be necessary to smooth the impact of drainage water on lowlands.

Acknowledgements. We specially acknowledge the valuable opinions, suggestions and recommendations of D. C. Le Maitre and one anonymous referee. We thank researchers and public agents of the Secretary of Agriculture and the Provincial Water Administration of La Pampa province, as well as the Instituto de Hidrología de Llanuras of Buenos Aires province for providing the statistical information to elaborate our data bases. We also acknowledge the financial support of INTA, SECyT in Argentina and a grant from the Inter-American Institute for Global Change Research (IAI, CRN II 2031), which is supported by the US National Science Foundation (Grant GEO-0452325).

Edited by: F. Laio 


\section{References}

Allison, G. B., Cook, P. G., Barnett, S. R., Walker, G. R., Jolly, I. D., Hughes, M. W.: Land clearance and river salinisation in the western Murray Basin, Australia, J. Hydrology, 119, 1-20, 1990.

Andréassian, V.: Waters and forests: from historical controversy to scientific debate, J. Hydrology, 291, 1-27, 2004.

Aradas, R. D., Lloyd, J., Wicks, J., and Palmer, J.: Groundwater problems in low elevations regional plains: The Buenos Aires province example, Groundwater and Human Development, edited by: Bocanegra, E. D., Martínez, and D., Massone, H., 613-623, 2002.

Bailey, R. G.: Description of the Ecoregions of the United States, Misc. Publ. No. 1391, USDA Forest Service, Washington, DC, USA, 1995.

Bosh, J. M. and Hewlett, J. D.: A review of catchment experiments to determine the effect of vegetation changes on water yield and evapotranspiration, J. Hydrology, 55, 3-23, 1982.

Briske, D. D., Fuhlendorf, S. D., and Smeins, F. E.: A unified framework for assessment and application of ecological thresholds, Rangeland Ecology and Management, 59, 225-236, 2006.

Buringh, P. and Dudal, R.: Agricultural land use in space and time, in: Land Transformation in Agriculture SCOPE, edited by: Wolman, M. G. and Fournier, F. G. A., John Wiley \& Sons, 9-45, 1987.

Calder, I. R.: Water use by forests, limits and controls, Tree Physiology, 18, 625-631, 1998.

Carcova, J., Maddonni, G. A., and Ghersa, C. M.: Long-Term Cropping Effects on Maize Crop Evapotranspiration and Grain Yield, Agron. J., 92, 1256-1265, 2000.

Carignano, C.: Late Pleistocene to recent climate change in Córdoba Province, Argentina: Geomorphological evidence, Quaternary International, 57/58, 117-134, 1999.

Clark, J. S., Carpenter, S. R., Barber, M., Collins, S., and Dobson, A.: Ecological forecasts: an emerging imperative, Science, 293, 657-660, 1988.

Díaz Zorita, M., Pepi, M., and Grosso, G.: Estudio de las precipitaciones en el oeste bonaerense, Publicación Técnica No 23, EEA INTA General Villegas, Buenos Aires, Argentina, 15 pp., 1998.

Doorenbos, J. and Pruitt, W. O.: Crop Water Requirements, FAO Irrigation and Drainage Paper No 24, Rome, 1977.

Elwell, H. A. and Stocking, M. A.: Vegetal cover to estimate soil erosion hazard in Rhodesia, Geoderma, 15, 61-70, 1976.

Evans, R.: Extent, frequency and rates of rilling of arable land in localities in England and Wales, in: Farm Land Erosion in Temperate Plains Environment and Hills, edited by: Wicherek, S., Elsevier, Amsterdam, The Netherlands, 177-190, 1993.

Faulkner, H.: Vegetation cover density variations and infiltration patterns on piped alkali sodic soils: Implications for the modelling of overland flow in semi-arid areas, in: Vegetation and Erosion, edited by: Thornes, J. B., Processes and Environments, Wiley, Chichester, UK, 363-384, 1990.

Ferdowsian, R. and Bee, G.: The role of groundwater depth on the hydrological benefits of Lucerne and the subsequent recharge value, Proceedings of the 13th Agronomy Conference, The Australian Society of Agronomy, The Regional Institute Ltd., online available at: www.regional.org.au/au/asa, 2006.

Francis, C. F. and Thornes, J. B.: Runoff hydrographs from three Mediterranean vegetation cover types, in: Vegetation and Erosion, Processes and Environments, edited by: Thornes, J. B., Wi- ley, Chichester, UK, 363-384, 1990.

Fullen, M. A.: Soil compaction, hydrological processes and soil erosion on loamy sands in East Shropshire, England, Soil Tillage Research, 29, 17-29, 1985.

Fuschini Mejía, M. C.: El Agua en las Llanuras (UNESCO, Oficina Regional de Ciencia y Tecnología para América Latina y el Caribe), Montevideo, Uruguay, 59 pp., 1994.

Gardiol, J. M., Serio, L. A., and Della Maggiore, A. I.: Modelling evapotranspiration of corn (Zea mays) under different plant densities, J. Hydrol., 271, 188-196, 2003.

Gilfedder, M., Smitt, C., Dawes, W., Petheram, C., Stauffacher, M., and Walker, G.: Impact of increased recharge on groundwater discharge: development and application of a simplified function using catchment parameters, Landscape and Industries, CSIRO/CRC/MDBC Publications, Canberra, Australia, 28 pp., 2003.

Hall, A., Rebella, C., Ghersa, C., and Culot, P.: Field-crop systems of the Pampas, edited by: Pearson, C., in: Field Crop Ecosystems, Elsevier, Amsterdam, The Netherlands, 413-450, 1992.

Hornbeck, J. W., Adams, m. B., Corbett, E. S., Verry, E. S., Lynch, J. A.: Long-term impacts of forest treatments on water yield: a summary of northeastern USA, J. Hydrol, 150, 323-344, 1993.

IPCC: Climate Change 2007: The Physical Science Basis. Summary for Policy Makers, Working Group 1 Report, Geneva, 18 pp., 2007.

Iriondo, M.: Map of the South American plains-its present state, Quaternary of South America and Antartic Peninsula, 6, 297308, 1990.

Iriondo, M.: Climatic changes in the South American plains: Records of a continent-scale oscillation, Quaternary International, 57/58, 93-112, 1999.

Jeong, H., Tombor, B., Albert, R., Oltvai, Z. N., and Barábasi, A. L.: The large-scale organization of metabolic networks, Nature, 407, 651-654, 2000.

Jobbágy, E. G. and Jackson, R. B.: Groundwater use and salinization with grassland afforestation, Global Change Biology, 10, 1299-1312, 2004.

Jobbágy, E. G., Nosetto, m. D., Santoni, C. S., and Baldi, G.: El desafío ecohidrológico de las transiciones entre sistemas leñosos y herbáceos en la llanura Chaco-Pampeana, Ecología Austral., 18, 305-322, 2008.

King, A. W.: Considerations of scale and hierarchy, in: Ecological Integrity and the Management of Ecosystems, edited by: Woodley, S., Kay, J., and Francis, G., St. Lucie Press, Delray Beach, Florida, USA, 19-45, 1993.

Kruse, E.: El agua subterránea y los procesos fluviales en la región centro-oriental de la provincia de Buenos Aires, in: Situación Ambiental de la Provincia de Buenos Aires, CIC II: 13-31, 1992.

Kruse, E., Forte Lay, J. A., Aiello, J. L., Basualdo, A., and Heinzenknecht, G.: Hydrological processes on large flatlands. Case study: Northwest region of Buenos Aires province (Argentina), Remote Sensing and Hydrology 2000, IAHS Publication, 267, 531-536, 2001.

Kruse, E. and Zimmermann, E.: Hidrogeología de Grandes Llanuras. Particularidades en la Llanura Pampeana (Argentina), Workshop publication on Groundwater and Human Development, 2025-2038, Mar del Plata, Argentina, 2002.

Lee, C. R. and Skogerboe, J. G.: Quantification of erosion control by vegetation on problem soils, in: Soil Erosion and Conserva- 
tion, edited by: Swaify, A., Moldenhauer, W. C., and Lo, A., Soil Conservation Soc. of America, 437-444, 1985.

Le Maitre, D. C. and Versfeld, D. B.: Forest evaporation models: relations between stand growth and evaporation, J. Hydrol., 193, 240-257, 1997.

Malagnino, E. C.: Late Pleistocen to late Holocene evolution of the paleodesert of the central region of Argentina and its paleoclimatic implications, International Conference on Desert Landscapes, International Geological Correlation Program, Project 252, Australia, 1991.

Manfreda, S. and Fiorentino, A.: A stochastic approach for the description of the water balance dynamics in a river basin, Hydrol. Earth Syst. Sci., 12, 1189-1200, 2008, http://www.hydrol-earth-syst-sci.net/12/1189/2008/.

McNeill, J. R. and Winiwarter, V.: Breaking the sod: humankind, history and soil, Science, 304, 1627-1629, 2004.

Meyboom, P.: Mass transfer studies to determine the groundwater regime of permanent lakes in hummocky moraine of western Canada, J. Hydrol., 5, 117-142, 1967.

Meyer, W. S., Barrs, H. D., Mosier, A. R., and Schaefer, N. L.: Response of maize to three short-term periods of waterlogging at high and low nitrogen levels on undisturbed and repacked soil Irrigation Science, 8, 257-272, 1987.

Moncaut, C. A.: Inundaciones y Sequías en la Pampa Bonaerense 1576-2001, Editorial El Aljibe, City Bell (Argentina), 102 pp., 2001.

Montaldo, N., Rondena, R., and Albertson, J. D.: Parsimonious modeling of vegetation dynamics for eco-hydrological studies of water-limited ecosystems, Water Resour. Res., 41, W10416, doi:10.1029/2005WR004094, 2005.

Newman, B. D., Wilcox, B. P., Archer, S. R., Breshears, D. D., Dahm, C. N., Duffy, C. J., McDowell, N. G., Phillips, F. M., Scanlon, B. R., and Vivoni, E. R.: Ecohydrology of water-limited environments: A scientific vision, Water Resour. Res., 42, 1-15, 2006.

Nosetto, M. D., Jobbágy, E. G., and Paruelo, J. M.: Land use change and water losses: the case of grassland afforestation across a soil textural gradient in central Argentina, Global Change Biol., 11, 1101-1117, 2005.

O’Neill, R. V., Turner, S. J., Cullinan, V. I., Coffin, D. P., Cook, T., Conley, W., Brunt, J., Thomas, J. M., Conley, M. R., and Gosz, J.: Multiple landscape scales: an inter-site comparison, Landscape Ecology, 5, 137-144, 1991.

Paruelo, J. M. and Sala, O. E.: Caracterización de las inundaciones en la Depresión del Salado (Buenos Aires, Argentina): Dinámica de la napa freática, Turrialba, 40, 5-11, 1990.

Peters, D. P. C., Pielke, S. R., Bestelmeyer, B., Allen, C. D., Munson-McGee, S., and Havstad, K. M.: Cross-scale interactions, nonlinearities, and forecasting catastrophic events, Proceedings of the National Academy of Sciences USA, 101, 15130-15135, 2004.

Rial, J. A., Pielke, R. A., Beniston, M., Claussen, M., Canadell, J., Cox, P., Held, H., de Noblet-Ducoudré, J., Prinn, R., Reynolds, J. F., and Salas, J. D.: Nonlinearities, feedbacks and critical thresholds within the earth's climate system, Clim. Change, 65, 11-38, 2004.

Rodríguez-Iturbe, I., Isham, V., Cox, D. R., Manfreda, S., and Porporato, A.: Space-time modelling of soil moisture: Stochastic rainfall forcing with heterogeneous vegetation, Water Resour.
Res,, 42, W06D05, doi:10.1029/2005WR004497, 2006.

Saravia, J. R., Benavidez, R. Canziani, O., Ferreiro, V., and Hernández, M. A.: Lineamientos Generales y Regionales para un Plan Maestro de Ordenamiento Hídrico del Territorio Bonaerense, Convenio Ministerio de Obras y Servicios Públicos de la Nación-Provincia de Buenos Aires, 323 pp., 1987.

Satorre, E.: Production systems in the Argentine Pampas and their ecological impact, in: The impact of Global Change and Information on the Rural Environment, edited by: Solbrig, O., di Castri, F., and Paalberg, R., Harvard University Press, Cambridge, MA, USA, 81-102, 2001.

Scanlon, B. R., Reedy, R., Stonestrom, D. A., Prudic, D. E., and Dennehy, K. F.: Impact of land use and land cover change on groundwater recharge and quality in the southwestern USA, Global Change Biol., 11, 1577-1593, 2005.

Scarpati, O. E., Spescha, L., and Capriolo, A. D.: The impact of the heavy floods in the Salado River basin, Buenos Aires province, Argentina, Mitigation and Adaptation Strategies for Global Change, 7, 285-301, 2002.

Scheffer, M., Carpenter, S., Foley, J. A., Folkes, C., and Walker, B.: Catastrophic shifts in ecosystems, Nature, 413, 591-596, 2001.

Smith, L. C.: Satellite remote sensing of river inundation area, stage, and discharge: a review, Hydrol. Proc., 11, 1427-1439, 1997.

Sophocleus, M.: Interactions between groundwater and surface water: the state of the science, Hydrogeol. J., 10, 52-67, 2002.

Tanco, R. and Kruse, E.: Prediction of seasonal water-Table fluctuations in La Pampa and Buenos Aires, Argentina, Hydrogeol. J., 9 (4), 339-347, 2001.

Tóth, J.: A theoretical analysis of groundwater flow in small drainage basins, J. Geophys. Res., 68, 4785-4812, 1963.

Tóth, J.: A conceptual model of the groundwater regime and the hydrogeologic environment, J. Hydrol., 10, 164-176, 1970.

Viglizzo, E. F., Lértora, F., Pordomingo, A. J., Bernardos, J., Roberto, Z. E., and Del Valle, H.: Ecological lessons and applications from one century of low external-input farming in the pampas of Argentina, Agriculture, Ecosys. Environ., 83, 65-81, 2001.

Viglizzo, E. F., Pordomingo, A. J., Buschiazzo, D., and Castro, M. G.: A methodological approach to assess cross-scale relations and interactions in agricultural ecosystems of Argentina, Ecosystems, 8, 546-558, 2005.

Viglizzo, E. F., Pordomingo, A. J., Castro, M. G., Lértora, F. A., and Bernardos, J. N.: Scale-dependent controls on ecological functions in agroecosystems of Argentina, Agriculture, Ecosys. Environ., 101, 39-51, 2004.

Viglizzo, E. F., Roberto, Z. E., Lértora, F. A., López Gay, E., and Bernardos, J.: Climate and land-use change in field-crop ecosystems of Argentina, Agriculture, Ecosys. Environ., 66, 61-70, 1997.

Wagenet, R. J.: Scale issues in agroecological research chains, Nutrient Cycling in Agroecosystems, 50, 23-34, 1998.

Ward, P., Dolling, P., and Duning, F.: The impact of Lucerne phase in a crop rotation on groundwater recharge in South-West Australia, Proceedings of the 13th Agronomy Conference, The Australian Society of Agronomy, The Regional Institute Ltd., available at: www.regional.org.au/au/asa/,2006.

Wilcox, B. P., Seyfried, M. S., and Breshears, D. D.: The water balance on rangelands, in: Encyclopedia of Water Science, edited 
by: Stewart, B. A., Howell, T. A., and Dekker, M., New York, USA, 791-794, 2003.

Wilcox, B. P. and Thurow, T. L.: Emerging issues in rangeland ecohydrology: vegetation change and the water cycle, Rangeland Ecology and Management, 59, 220-224, 2006.

Winter, T. C.: Relation of streams, lakes, and wetlands to groundwater flow systems, Hydrogeol. J., 7, 28-45, 1999.

Withers, P. J. A., Hodgkinson, R. A., Bates, A., and Withers, C. L.: Soil cultivation effects on sediment and phosphorus mobilization in surface runoff from three contrasting soil types in England, Soil Till. Res., 93, 438-451, 2007.
Zárate, M.: Loess of southern South America, Quat. Sci. Rev., 22, 1987-2006, 2003.

Zarrilli, A.: Producción Agraria y Transformaciones Ecológicas en la Argentina. Los Límites de la Producción Rural Pampeana. 1930-1950, X Congreso Nacional y Regional de la Historia, Santa Rosa (La Pampa), Argentina, 1999.

Zhang, L., Dawes, R. W., and Walker, G. R.: Response of mean annual evapotranspiration to vegetation changes at catchment scale, Water Resour. Res., 37, 701-708, 2001. 